\title{
A Review of Simarongarh's History on Its Nexus Areas with References of Archaeological Evidences
}

\author{
Prakash Darnal
}

\begin{abstract}
After the Lichachhavi period, Nepal was bounded within the Kathmandu valley only. Sinja emerged as a powerful state in the west of Nepal. Likewise, Karnata dynasty became strong and powerful to the south of Nepal in the beginning of 10th and 11th century A. D. They were so strong and powerful that they attacked Kathmandu valley several times and plundered for the sake of wealth. So Simraongarh was once an important medieval kingdom of Nepal. It was established by Karnata dynasty Nanyadev in 1097 A. D. After capturing Mithila, Nanyadev began to rule it from Simraongarh. He has been credited in the records for the unification of Tirhut. Under the Karnatas Tirhut had developed on economic, social and cultural which was also known as golden age. They ruled over Mithila for about 227 years and after that Gayasuddin Tuglak conquered. Muslims ruled about three hundred years, and then it came under Sens of Makawanpur. Lohang Sen had extended his territories up to Vijayapur. When Prithivi Narayan Shah conquered Makawanpur in 1762 A. D. all part of eastern Terai including Tirhut or Mithila became integral part of Nepal. After the Anglo Nepal war in 1814 - 16 A.D., Nepal lost some parts of eastern Terai, it came again under its jurisdiction in Sugauli Treaty of 1816 A.D. But now people seem to forget Simarongarh which was once so rich and highly developed. Therefore, the objective of this article is not only to remind of its glorious past history but also to prove how important this area through archaeological findings.
\end{abstract}

Keywords: videha, Tirhut, Mithila, labyrinth fort, Paleolithic, Neolithic, Mesolithic, terracotta

\section{Introduction}

Simraongarh was once an important medieval kingdom of Nepal. It was established by Karnata dynasty Nanya Dev in 1097 A. D. After capturing Mithila, Nanya Dev began to rule it from Simraongarh. He has been credited in the records for the unification of Tirhut after launching several successful wars. Under the Karnatas, Tirhut had developed economic, social and cultural sector which was also known as Golden age. They ruled over Mithila for about 227 years

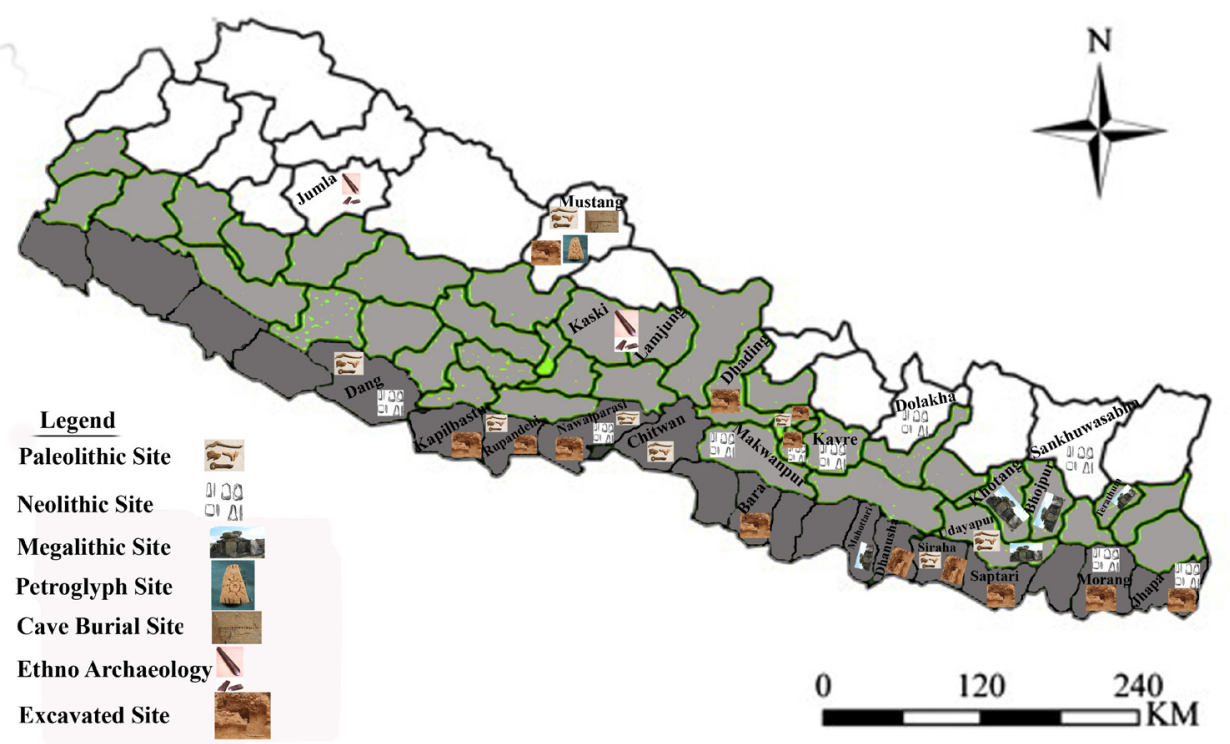

and after that Gayasuddin Tuglak conquered. Muslims ruled about three hundred years, then it came under Sens of Makawanpur (Pandey,1999, p. 184). Lohang Sen had extended his territories up to Vijayapur. When Prithivi Narayan Shah conquered Makawanpur in 1762A.D., all part of eastern Terai including Tirhut or Mithila became integral part of Nepal. After the Anglo Nepal war in 1814 16 A.D., Nepal lost some parts of eastern Terai, but it came again under its jurisdiction in Sugauli Treaty of 1816 A.D.

\section{History in Brief}

According to Satpatha Brahmana, Videha was bounded on the north by the foothill of Himalaya and on the east, south and west by the rivers Koshi, Ganga and Gandaki respectively. Its capital was Mithila which was also famous as Janakpur.

Ramniwas Pandey had said, "The Satpatha Brahmana mentions that it was Videha Madhava who laid the foundation of the Janaka dynasty and Aryan culture in the region, however, the Purans give this credit to Nimi 
Videha. Pargitar minutely studied the Puranas and the Ramayana and he came to the conclusion that 94 kings of Janaka dynasty ruled over Mithila. King Siradhvaja Janaka -circa 1500 B. C.,the father of Sita, happened to be the most illustrious ruler of Videha. During his rule there was much prosperity in the kingdom and wise men greatly devoted their mite to the cause of promoting religion and philosophy, conducive to the eternal peace of mind and salvation in the end. The court of the king was graced with the scholars such as Satyakama Javala, Aruna Asvapati, Svetaketu, Yajnavalkya and Gargi, who were not only profound scholars but also great social reformers . For their painstaking efforts Hinduism and Varnasram Vyavastha firmly established themselves in Videha and the kingdom became an ideal Hindu state (Pandey, 1999, p. 182)."

Karnata dynasty Nanya Dev began to rule Mithila from Simraogarh in 1097 A.D. The name Simraongarh was derived from the Simal tree (locally called simar ) which was plentiful at that time. Nanya Dev, Ganga Dev, Narsingh Dev, Ramsingh Dev, Shaktisingh Dev and Harsingh Dev were the famous Karnatas rulers in Simraongarh. Likewise, Shreedhar, Ramaditya Thakkur, Karmaditya Thakkur, Vireswor, Ganeswor and Chandewor were worthy and influential ministers. During the period of Karnatas rulers, the economic, political, religion, literary and artistic development was reached in such a height that which was considered a golden age in the history of Simraongarh.

Gayasuddin Tuglak, the Tughlak dynasty king of Delhi defeated king Harsinghdev and destroyed the labyrinth fort of Simraongarh in 1324 A.D. which made Harsingh dev to flee with his family to Tinpatan of Dolakha, where he died.

The Tibetan monk Dharmaswami who travelled from Tibet to Nalanda, stayed in Nepal. When he passed through 'Pa-ta' that is Simraongarh during the year 1234 and 1236 A.D. As cited by Mohan Khanal "he describes his meeting with king Ramsingh deva and says, In this country there was a town called 'Pa-ta' which had some 600,000 houses and was surrounded by seven walls. The height of these walls was about equal to that of a Tibetan fort. Outside of the town walls stood the Rajas Palace which had eleven large gates and was surrounded by twenty one ditches filled with water and rows of trees. There were three gates facing each direction, East, West and South, and two gates facing North ..... but the others had bridges were stationed more than ten archers at each bridge .... It was also said that there were three men exports in Swordmanship( p.5 8)" ( Khanal, 2056,15/16) .

The Italian Capuchin Missionary Fr. Cassiano of Macerta visited Nepal valley many times between 1739 and 1754 A.D. In 1792 William Kirkpatrick had passed through the site of Simraun and in 1835 Brian Hodgson, the British scholar - diplomat and Resident of British Legation in Kathmandu also went down to witness with his own eyes the ruins of Simraungarh. He has remarked about the high quality of the sculptural art he found there (Sharma, 2056).

\section{Background of Archaeology}

The history of prehistory begins with the Paleolithic period because, apart from discovery of a Ramapithecus tooth in the Tinau Khola ( Butwal ) in 1980 by a Nepal - US team, there have been no major hominoid fossils discovered in the Himalayan foothills of Nepal . That tooth, an upper molar dated to $9-11$ mya ( million year ago), was an important find as it is the oldest hominoid specimen in Asia ( Shah and Shrestha,1992) and its existence suggests the possibility that other hominoid and even hominine fossils may be found in Nepal .

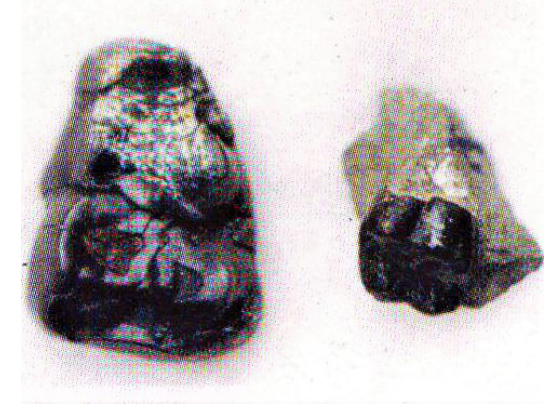

Preserved Teeth, Photo: Natural History Museum, Swayambhu

"Gudrun Corvinus has contributed unforgettable work in the prehistory of Nepal. She remains the most successful Paleolithic archaeologist in Nepal, having discovered a large number of prehistoric sites - ranging from the Paleolithic to Neolithic period - as part of the Geo-archaeological Project in Nepal, an endeavor jointly sponsored by the German Research Council, Tribhuvan University (Kathmandu), and the Government of Nepal's Department of Antiquities (DoA).

Corvinus focused primarily on performing basic research in the dun region of the Siwalik Hills, the DangDeokhuri district of western Nepal and the Ratu River banks in Mahottari district of eastern Nepal. This work resulted in many important discoveries and Corvinus can be credited with having put Nepal on the map of Paleolithic archaeology in South Asia. Handaxes have also been found in the basal gravel at Jhaijri in Gadari and at Satpati at the Himalayan front near where the Narayani River flows into the Satpati River of the southern plains.

Corvinus also discovered the Patu Industry of the Siwalik Hills near Kamala river and in the Ratu Khola in the Mahottari district of eastern Nepal. The Patu industry is predominantly a cobble (pebble) industry with unifacial choppers, knives, scrapers, unifacial core-scrapers, and adzes for heavy-duty work. The tools were manufactured by "splitting large quartzite cobbles along their natural cleavage planes. The split quartzite slices were then flaked and shaped into flat adze by stepflaking. The flakes were not worked and there were no microliths. The macrolithic character of this industry is similar to the Hoabinhian culture of the South-East Asian Mesolithic period of the early Pleistocene epoch. It is very common in Nepal but shares no 


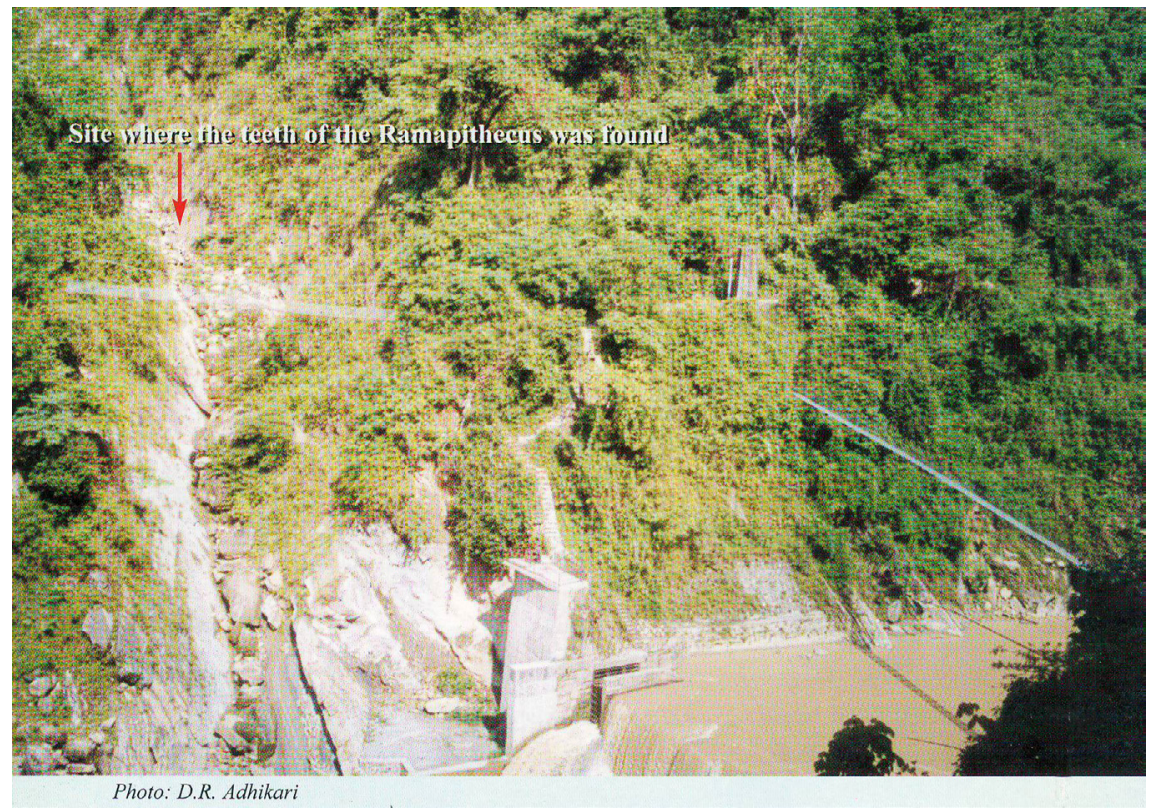

According to Kumar Lal Joshi, Paleolithic tools have also been reported from the forest of Belkatari, which is on the bank of river Koshi in the Thoksila village development committee of Udayapur district (Joshi, 1997, 81). Khaptedanda is in village called Dandatole of Govindapur village of ward no. 8 in Siraha. It is spread over $800 * 800$ meters. Pottery assemblage seen in Khaptedanda is enormous in variety. Almost all sorts of potsherds from Reed marked to Northern Black Polished.

affinities with Indian technological traditions. Radiocarbon dates suggest this industry dates to the Early Holocene, circa 7000 B.P. (6695+/-155 B.C.E.)". ( Darnal , 2016. 414/415 ).

Department of Archaeology and Instituto Italiano per il Medio ed Estermo Oriente ( IsMEO ) had jointly explored and excavated Simraongarh in 1991, 1992 and 1994 A.D. The ruin was surrounded by fortification wall which was extended to the area of $7.5 \mathrm{~km}$ long north- south and 4.5 $\mathrm{km}$ east -west (Tripathee, 2057, P 25 ). Jit Jung Rana built Ram Janaki temple at Raniwas in 1935 B.S. Destruction of archaeological site began to occur when the temple was built on the mound, and due to excavation of modern channels, digging of the earthen walls for leveling the fields and recovering bricks was a major factor of destruction of the city. Another factor is building unplanned houses and digging extensively for pond.

Massimo Vidale an archaeologist on behalf of IsMEO has promised to send report and wished to extend his cooperation for development of Simraongarh in future at his video message in the Simraongarh International Conference on May 18 and 19, 2018.

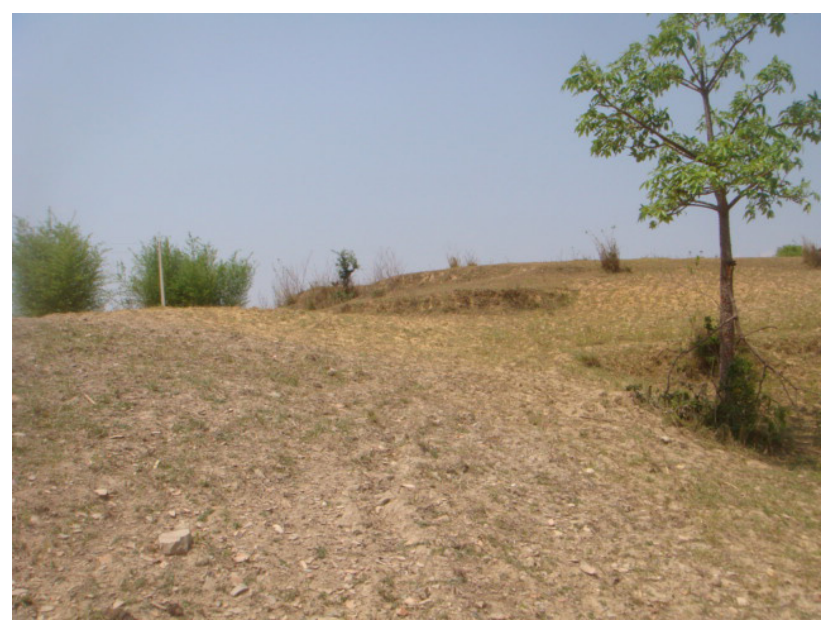

Khapte danda

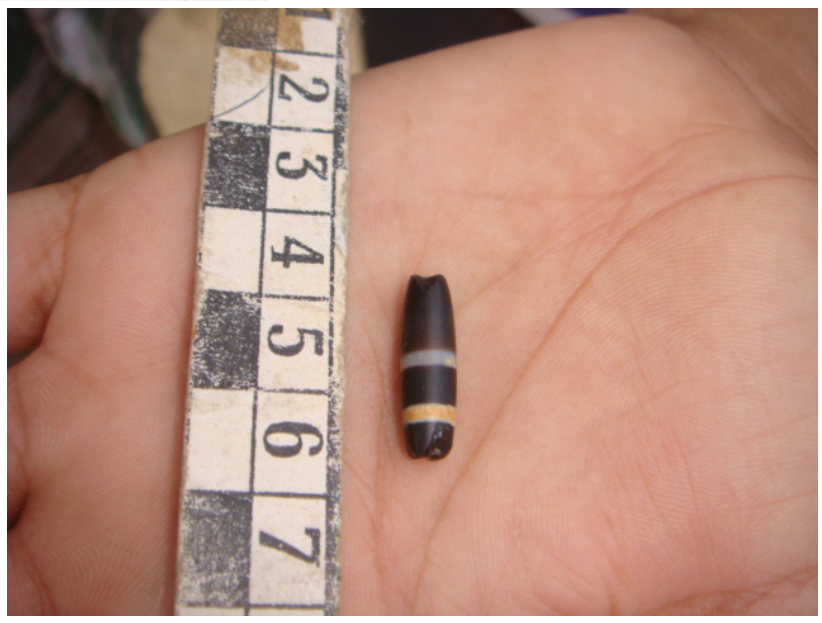

Ware could be collected from Neolithic to pre Christian era. This is the first site of its type traced in Eastern Nepal. No other NBPW sites so far to the east of Punditpur are yet discovered. Side by side the Neolithic Celts are also collected from the site showing the area to be Semi-precious stone bead occupied by the men from very early phase of history. This shows the area to be inhabited by men from at least Neolithic period down to the present day. If we can connect the study with Patu and Ratukhola Mesolithic sites it will definitely give nice picture of prehistoric phase in East Nepal (Shrestha, 2007,1/3).

Mukhiyapatti is located $16 \mathrm{~km}$ south east from Janaki temple, Dhanusha. It is in Musarahaniya village committee. Ancient idols were discovered while embanking the Jamuni river. DoA found sequential history after studying its antiquities.

Vidhyapati Garh situated in Bakhar ward no. 6 of Bhawanipur (Praganna Dhanchhabar) village development committee, Siraha was excavated by DoA in 2069/70. Three trenches were dug where floor with hearth was found. Few redware potsherds and metal pot of color was collected. 


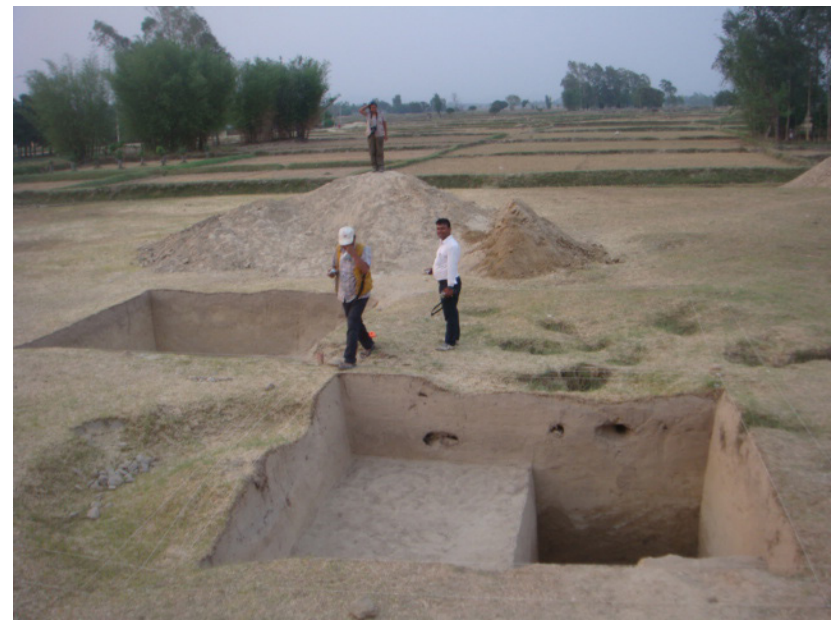

Vidhyapati Garh

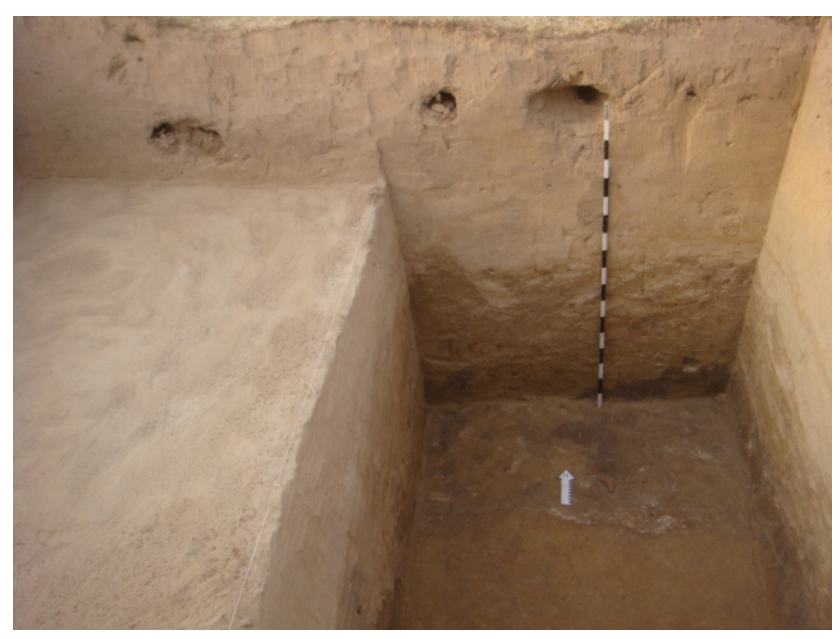

Trench of Vidhyapati Garh

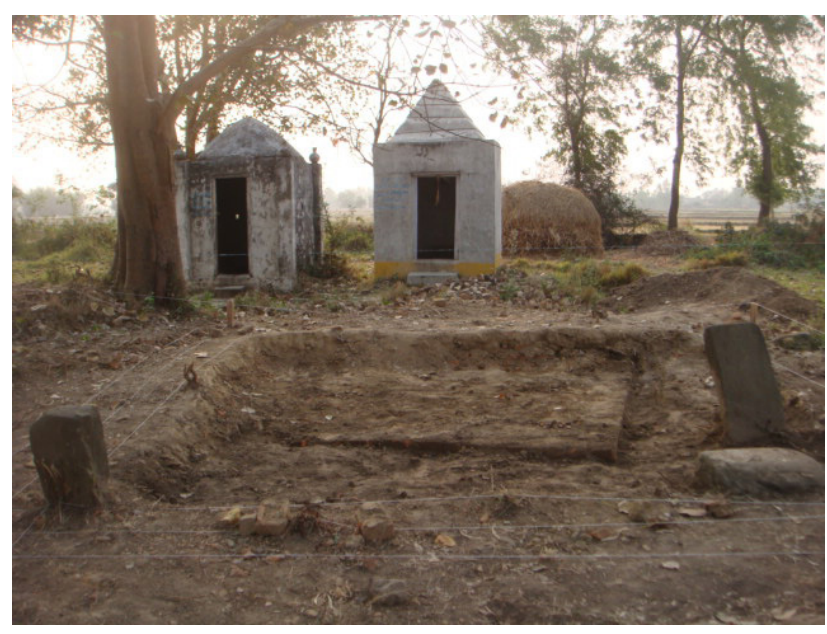

Dhangadhi Temple

Dhangadhi is also in Siraha district, Dhangadhi village development committee, ward No.1 and 5. There are two temples one is Dhangadhi Mai and another is Sahaleshwor. DoA had excavated here in 2061 / 62 B.S. and found course of stone. So to know further about this course, it again excavated in $2069 / 70$ B. S., but there was no trace of any monument. Stones found from the excavation were numbered and piled up there. These stones are Trench of Dhangadhi supposed to have been ruined stone temple of $18^{\text {th }}, 19^{\text {th }}$ Sen dynasty.

Mani Mandap is very famous religious site of Janakpur municipality, ward no. 13, Dhanusha District where it is believed that the marriage ceremony of legendary Ram and Sita was occurred. It is in south of Pidari Chowk, about half an hour walk only to reach Rani Bazar where Mani Mandap can be located.There is a pond Mani Mandap beside Mani Mandap called Sita Pokhari (pond) where Ram, Laxaman, Bharat and Shatrughan washed their feet. Mani Mandap is spread over $140 * 111$ meters. There is a temple of Ram and Sita in the center. Old Pittojiya Tree on the south of the temple is also very attractive.

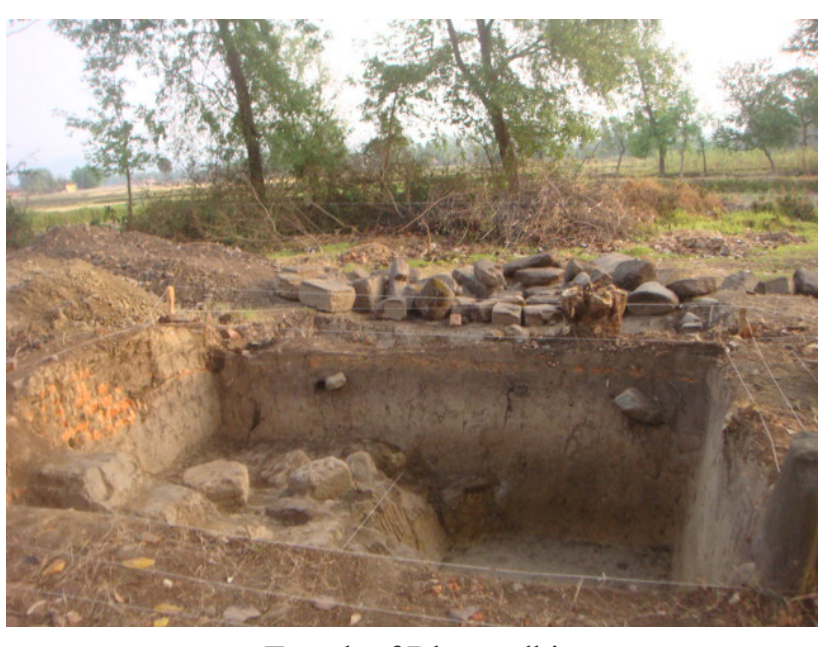

Trench of Dhangadhi

DoA had excavated here in 2070 B. S. for one week and found floor with potsherd, ashes and posthole in Trench no. I dug $2.50 \mathrm{~m}$. down, on west side of the temple. Trench no. II of quadrant I of north side of the temple was dug $2.28 \mathrm{~m}$. deep where hearth and posthole appeared. Likewise, Trench no. III of quadrant III which was laid $10 * 10 \mathrm{~m}$. at south of the temple was dug 2.70 m. deep. Two postholes and floor with ash and potsherds was reported. Some antiquities like 239 pieces of potsherd, iron ornament anklet (pawju ) and few iron were collected. On the second time in 2071 DoA laid four trenches. Trench I of quadrant III was excavated $3.38 \mathrm{~m}$ deep. Four layers were noted, terracotta potsherds and a hearth was recorded. Trench II was dug 2.73 down. Here a niche of baked brick painted by red mud was found. Charcoal and ashes were also there. Trench III was dug $2.51 \mathrm{~m}$. deep from where ashes, burnt red mud and four hearths were recorded. In the Trench IV, while digging $4.10 \mathrm{~m}$. deep, ash layer was found from $2.35 \mathrm{~m}$. to $3.25 \mathrm{~m}$. 


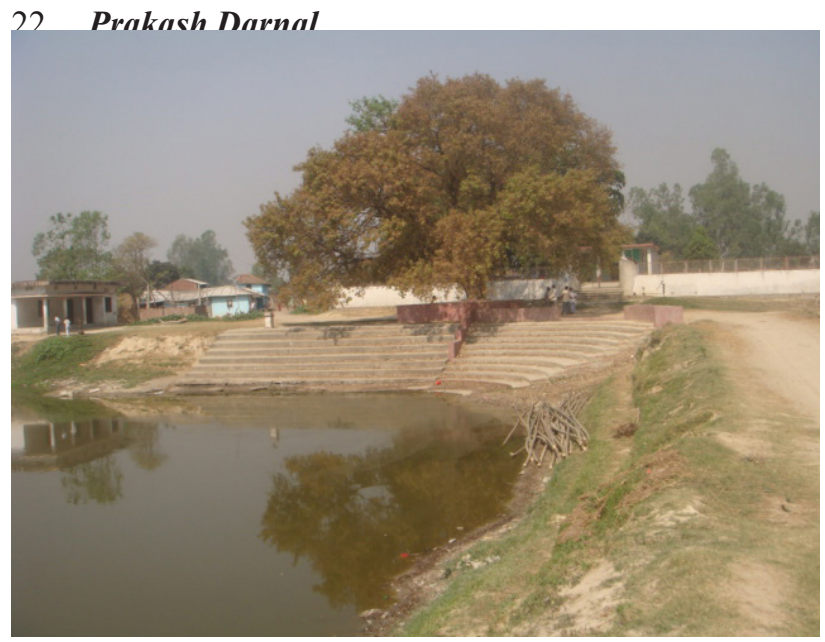

Mani Mandap

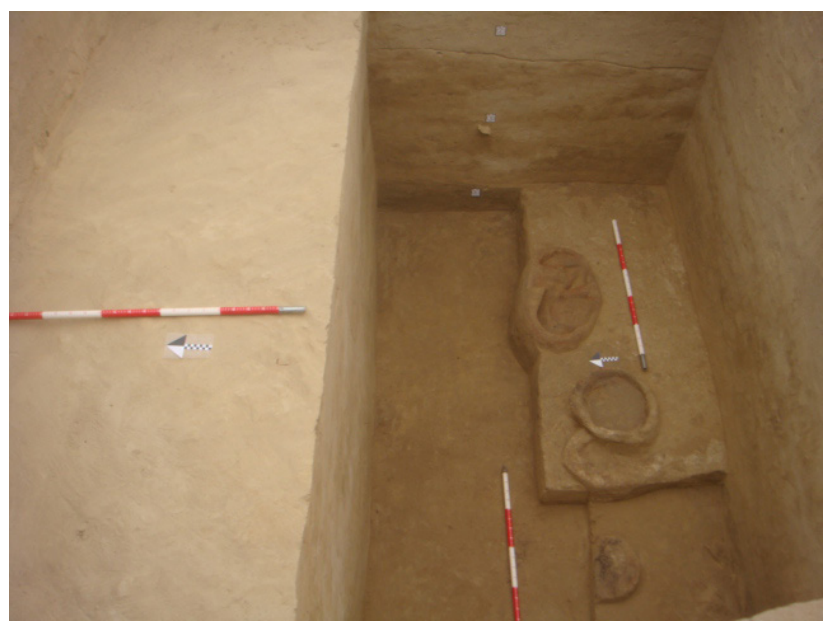

Trench, Mani Mandap

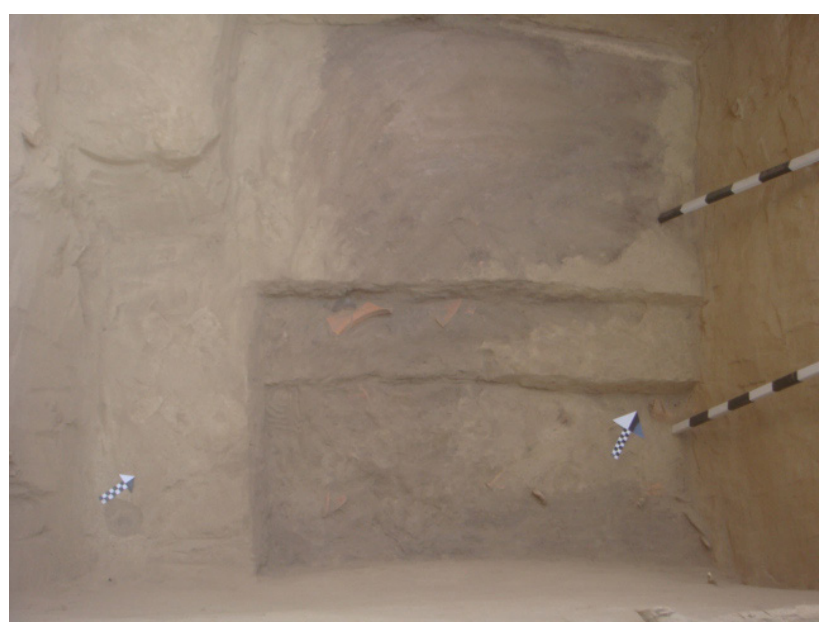

Trench, Mani Mandap

Cultural sequence or chronology could not be observed from Mani Mandap, only cultural patch had been noticed for short period. But potholes show their settlement was wattle and daub. Bricks structure could not be found.

\section{Khoksar Excavation in 2061/2062 B.S.}

Khoksar site is located in Sagarmatha zone, Saptari district, Khoksar Parbaha village development committee, ward no. 6 of Kanakpatti village.

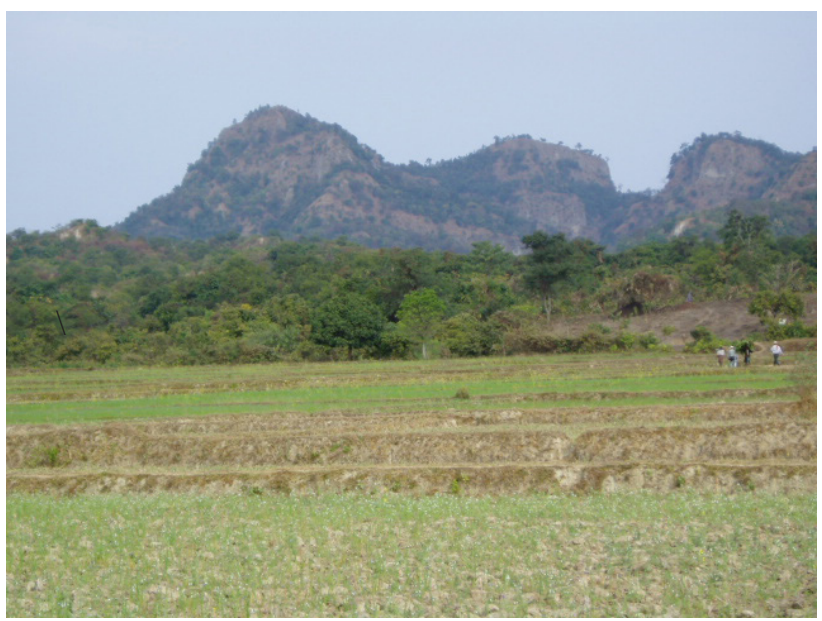

Khoksar Site

Chandrabhaga Bhagawati is located $2 \mathrm{~km}$ away from Khoksar site on the north west of Chure. It is believed to be tutelary deity established by the king named Chandraketu in 15 th century. Saphalya Amatya has mentioned about Kancha Khoriya (Gadhi) and Chandrabhaga ruins. He had emphasised to excavate the ruins because he assumed it as fort, palace and temple (Amatya, 1979, p.15).

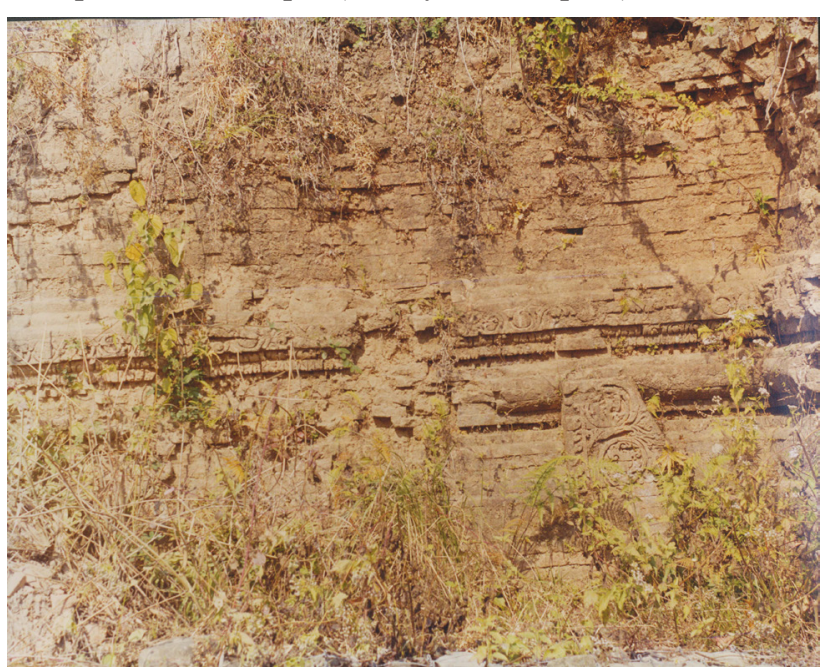

Exposed wall by rain

After a decade Rajesh Mathema had got chance to explore this site. In his report "Yekagadh (Chandrabhaga), he had explained about the remains of walls, mounds and temple's ruins. He had also reported that stone artifacts seemed to belong to the period of Sen dynasty but the remains underneath the mound could be the evidence of Kusan and Gupta period. 


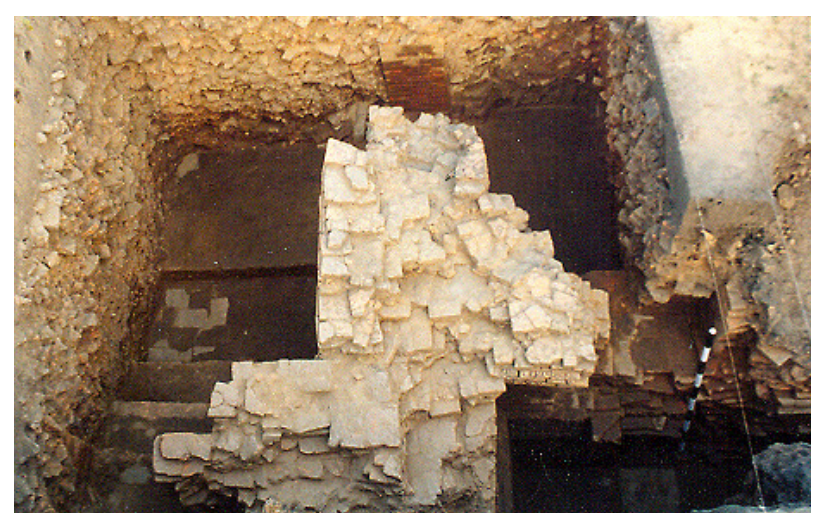

Trench of G5

In 2053 B. S. Govinda Ghimire and I had visited to Chadrabhaga ruin crossing the Khando, Banwari, Karaiya and Chadrabhaga river. After ascending a steep hill without trail, we descended towards northern slope where bricks and ten pieces of carved stones were scattered on the forest surface and in the river of Chandrabhaga.

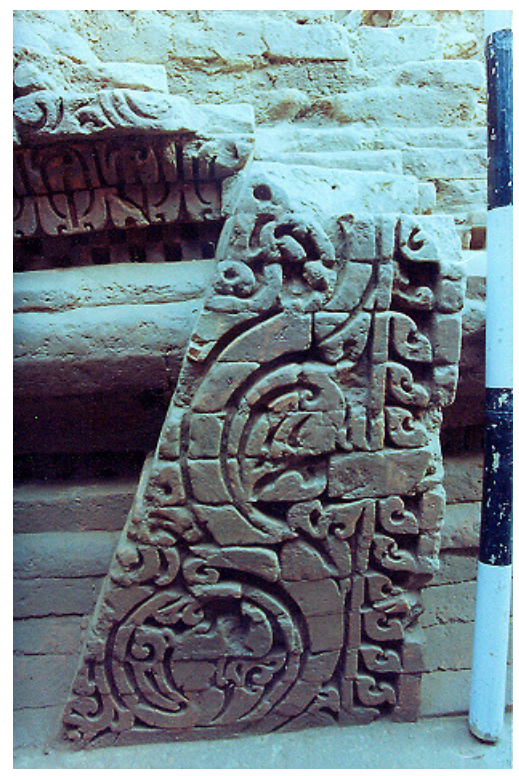

Trench of G6

Kumar Lal Joshi had published the report on "Prachin Bhagnabaseshko Purattatwik Anwesan" in Kantipur Koseli in 2054 Chaitra 22. He has written that mound was spread over five /seven Bigha. The mound seemed slender slope toward west south. There is Yekagadhi dry stream between southwest mound and exterior wall. Due to incessant rain in Asar of 2054 B.S. Yekagadhi got flooded and it washed away the southwest structure, exposing the beautiful carved brickwork. The exposed brick wall was 31' 8" long and its height was nearly 10'. It was accidental finding evidence, which could be of sanctum of an ancient temple. The exposed carved bricks, which contained motif of flora and geometric design, reminiscent the carved bricks of Lori Kudan of Kapilvastu dated 8th -9th century A. D. Finding of brick well, ruin of palace, pottery and terracotta animal figurine on surface, assessed the mound an ancient settlement. He has suggested ultimately, excavating the mound to know what exactly it is.

In 2054/55 Department of Archaeology had constructed Gabion wall for the protection of ancient carved structure. Department of Archaeology had sent a team in 2058 (Magh) for survey and trial excavation. The team found the mound spread over 30 Bigha.

Khoksar archaeological site is huge mound spread over 30 Bigha on the lap of Chure hill. About half kilometer long outer wall runs parallel to the mound which speculates that the ruin of the settlement is in rectangular pattern. The mound contains wall alignment on west north, four ruin of monument and two ancient well. Chandrabhaga is the most important ruin which nomenclature is mentioned in the ancient text. It seems that Khoksar and Chandrabhaga are main hub of cultural activities and other surrounding sites like Agni Sair, Shambhunath, Rajdevi, Boria katti, Lalapatti, Manraja, Kusmar village of Saswor V.D.C, Balawa and Rupnagar were grown as satellite in Saptari. Exploration of archaeological sites and sculptures in Saptari has shown strong affinity with Chandrabhaga and Khoksar. The G3 and H3 square was found covered by stone pavement with different letters, signs and motifs. Most of the stones were joined with iron dowels. Signs like bow and arrow, zero on boat, square flags and peacocks (?) were noteworthy which need to be study. There were 24 engraves on the two square and three on the surface. Antiquities were iron nails, iron dowels, iron chisel, arrow, drill bit, stone fragment of sculptures, terracotta pot, animal figure, toy, perforated pieces, Head of Narayan image, Siddha with beard, Buddha? (it is identified because of its deer figure) and a semi precious bead. These sculptures are the valuable findings which can be dateable by the comparative study. Iconography study shows that these sculptures belong to period of Pal dynasty $9^{\text {th }}-10^{\text {th }}$ century A. D. Prominent potsherds found were red ware but pottery like grey ware spouted pot and painted grey ware was important for the date and chronology. Sample of charcoal, shell and lime was also collected for the study and C14 dating. The evidence of the alignment of the south west exposed main structure was found in G6 (1) and G5 (4) and the section showed that the main structure still running through it on north side. There was two chamber in G6 (1), each having rammed mud floor and two opening on west main structure and one entrance between two chamber. Outer floor was also discovered on the west structure. The outer face of the structure consisted different carved bricks. It has also prominent projection of brick with geometric design. Likewise, the west facade of G5 (4) has three projection of brick reminiscent of Lori Kudan of Kapilvastu. Brick of duck and Sinkhwa was also found from the cornice of the structure. There was opening space probably window (?) on the west structure. The main structure was heading towards north and its other two arm spread in east side making chamber inside the structure. The floor was mud rammed with potteries in situ. The south structure was not seen on section, seemed gap for entrance where as the north structure continued towards east. The floor outside the west structure was also mud 
rammed but some portion of it was found stone pavement.

No dateable artifacts as coin and inscription were discovered. The structure still cannot be said exactly whether palace, temple or monastery. Further excavation is necessary to identify the structure and chronology of the culture. It is suggested that this site should be carry out Area Excavation along with archaeological conservation which would not only preserve the archaeological site but also promote the tourism and opens the pages of past history.

\section{Exploration of the Important Archaeological Site of Saptari District}

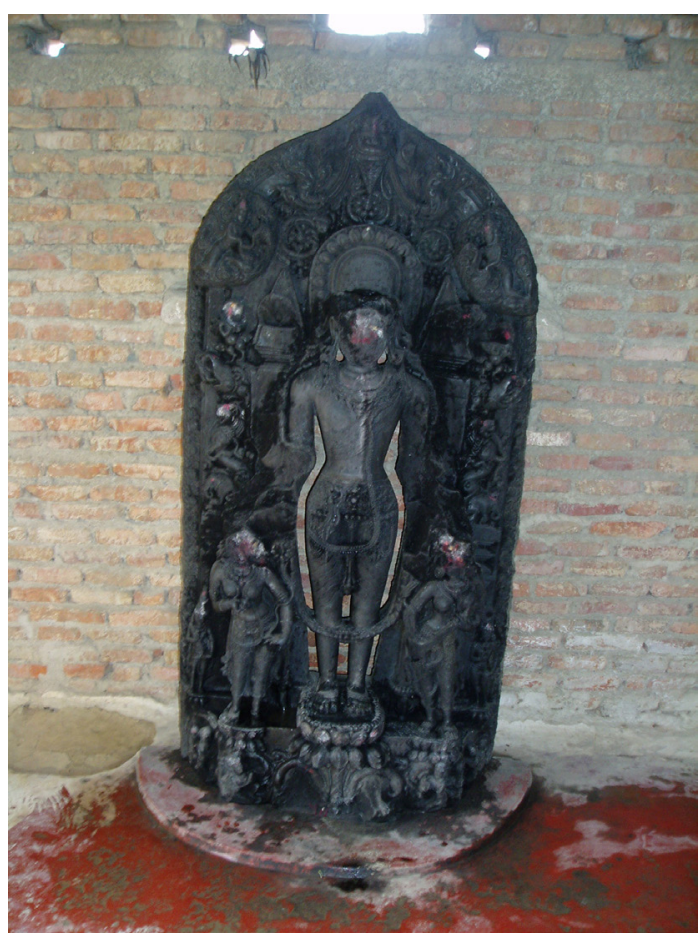

Vishnu, Kusmar, Saswor VDC

Saptari district has been known as the famous religious

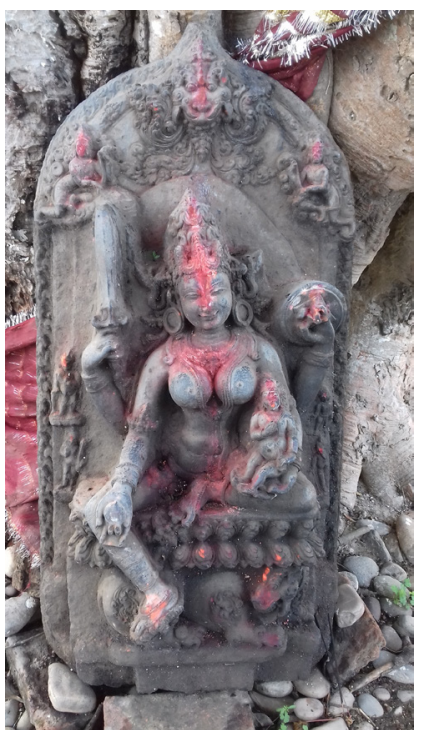

Parvati

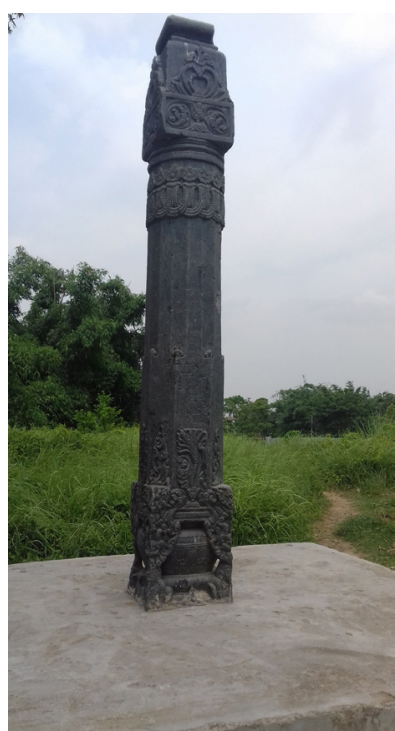

Artistic pillar

place of Vishnu, Kusmar, Chhinnamasta Bhagawati Shakhada, Rajdevi, Chandrabhaga. Shambhunath and Kankalimai. It comprises many archaeological site also for example, Lalapatti Pancheswor Mahadev, Theliya Bhediya Banshakhandi, Banainiya etc. But after the discovery of Khoksar site which had been carried out, excavation had been for two years only. Because only a few trenches have been excavated it will be early to determine the date and cultural sequence or chronology without further excavation. But the finding of painted grey ware and spouted grey ware pot has shown potentiality of period of Buddha or even before Buddha. Those findings have added a new horizon in the archaeology of Nepal. It seems that Khoksar was main hub of culture and other surrounding places were grown as satellite centre (Darnal, 2012).

\section{Conclusion}

Simarongarh was one of the most important sites which played vital role in the medieval period of Nepal's history. It was so powerful that they always tried to influence and invade Kathmandu valley. They had progressed in economic, social, art, literature and culture. Their tutelary goddess Tulaja Bhawani was brought to valley while king Harisingh Dev fled to Nepal which also later become tutelary goddess of Malla of the Kathmandu valley.

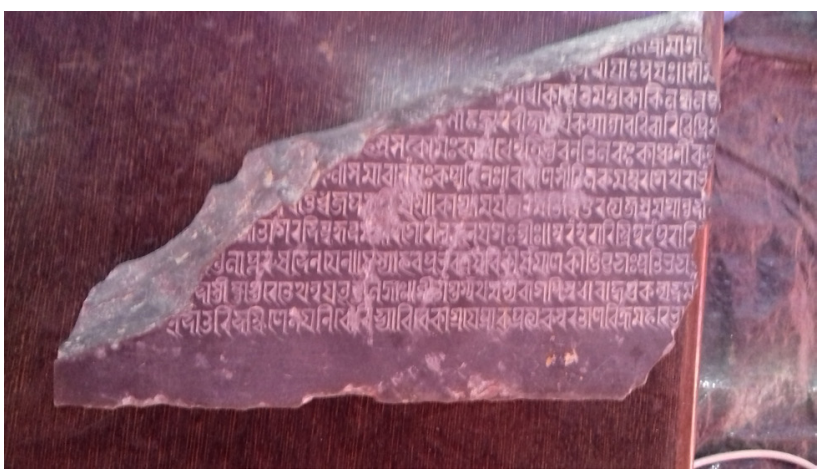

Stone Inscription

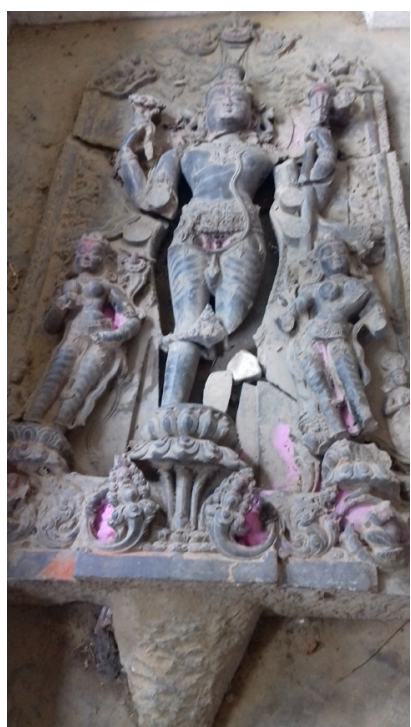

Visnu

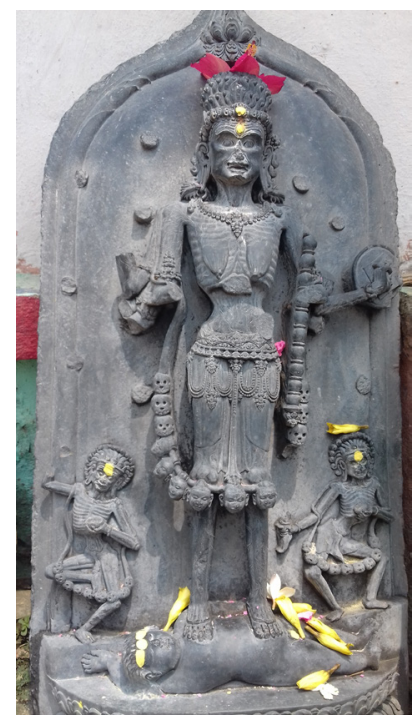

Chandika 


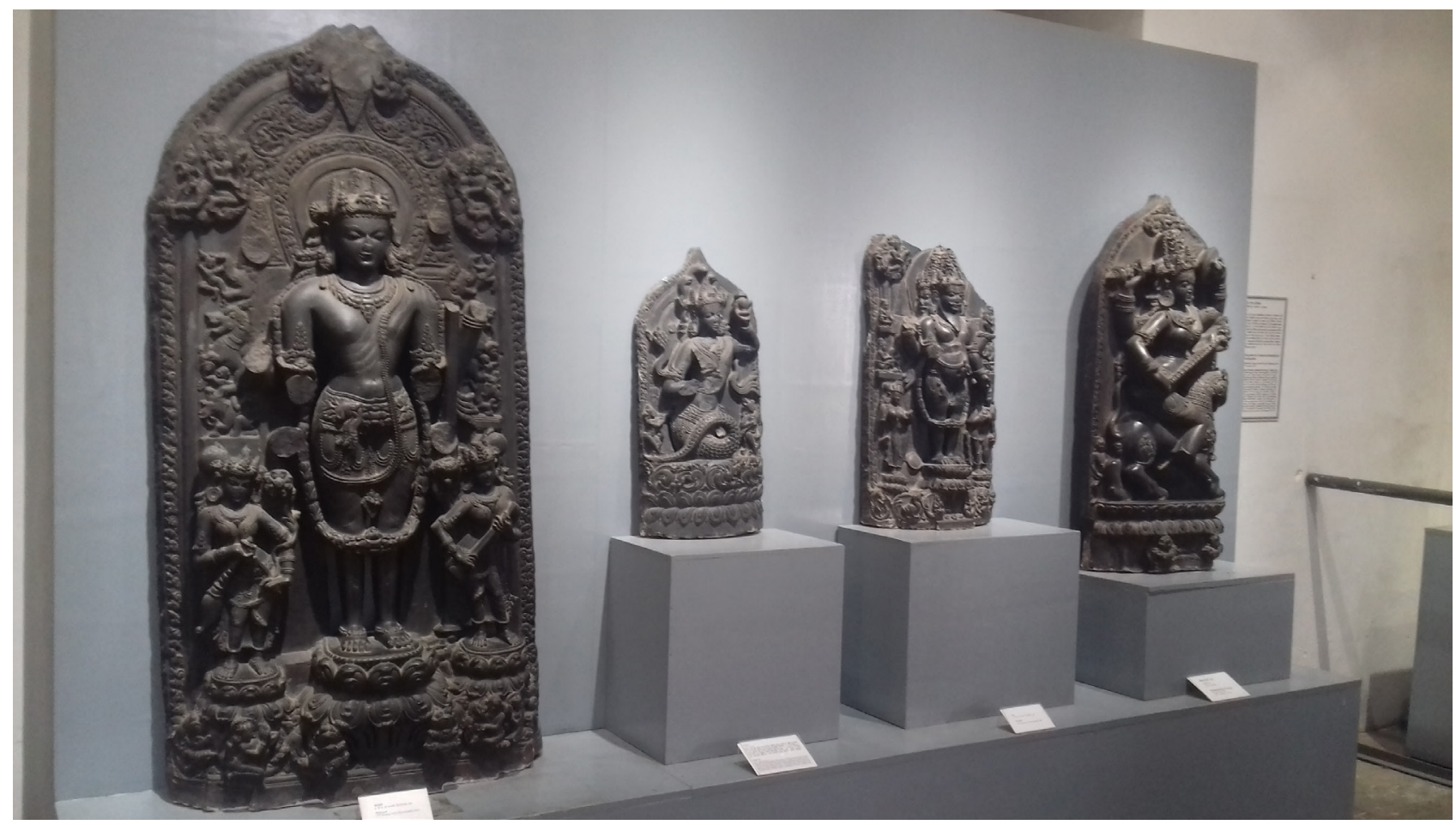

Sculpture from National Museum, Chhauni

There are still a lot of archaeological remains in Simarongarh, though most of the sites have already been destroyed, even though recent finding of artifacts like sculpture of Parvati, artistic stone architectural pillar, broken sculpture of Visnu and Fragment of stone inscription are evidences enough to study it seriously. As many scholars have praised the artistic and beautiful sculptures found from Simarongarh, are said to be influenced by art style of Pala Sena. These are made of black schist stone and mostly in life sized. Such sculptures are found from Valmiki Asram, Simarongarh, Murtiya, Janakpur, Saptari, Varaha Chhetra and Inarua. Few sculptures like Visnu, Nagraj, Singhavahini Durga and Brahma were brought from Simarongarh and kept in National Museum, Chhauni, with care and maintain. But the sculptures in Simarongarh are in such a pity and neglected condition. Don't they deserve to be treated equally like National Museum, Chhauni though they originated from the same place and period?

I had chanced to visit Simarongarh in 1994 with my senior colleague Mrs. Riddhibaba Pradhan who accompanied, then Ambassador's wife of Italy on behalf of DoA to observe the excavation done by Ismeo and DoA. The sculptures near Kankali temple were in a roofless home, seemed in miserable condition. After 24 years I got opportunity to attend in the Simarongarh International conference 2018 with Senior Archaeologist Tarananda Mishra and Deputy Director General of DoA, Mrs. Mandakini Shrestha. The situation, I found was a little bit better than previous time because most of the sculptures were kept inside the house except those discovered recently. The stone sculpture of
Parvati is holding Kumar by her left arm. She has four hands and in a posture of Lalita Asana. Kumar is sitting at her left lap. It was dug in the middle of 2017, is now in open under a tree inside the police station of Simarongarh. A beautiful decorative pillar was unearthed from Palatiya Mai which has been the original temple of Taleju goddess Bhawani. Likewise, a sculpture of Visnu broken into many pieces has been kept in a public house. It can be conserved by chemist conservator. A fragment of stone inscription and a pillar was also discovered when digging a field. The pillar is without any motif, but the inscription came to be known Vishnu of Janakapur as part of previously found inscription of king Ram Singh Dev.

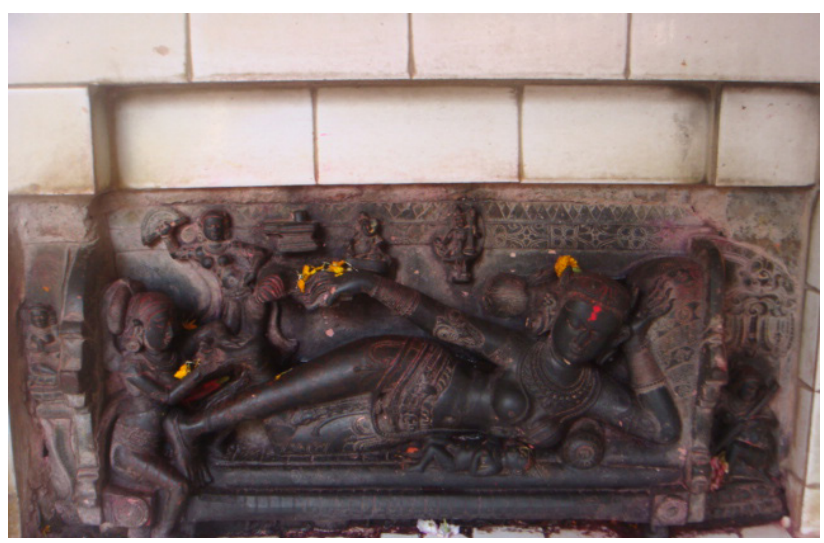

Saddhyojata of Ram Temple,Janakpur

The concern authorities should not delay to preserve and study further in detail the important sculptures as well as history of Simarongarh. It is a famous historical site 
described as Labyrinth fort, but not only that the area is also a prehistoric site. Therefore, Simarongarh is very potential archaeological site for exploration, investigation and excavation.

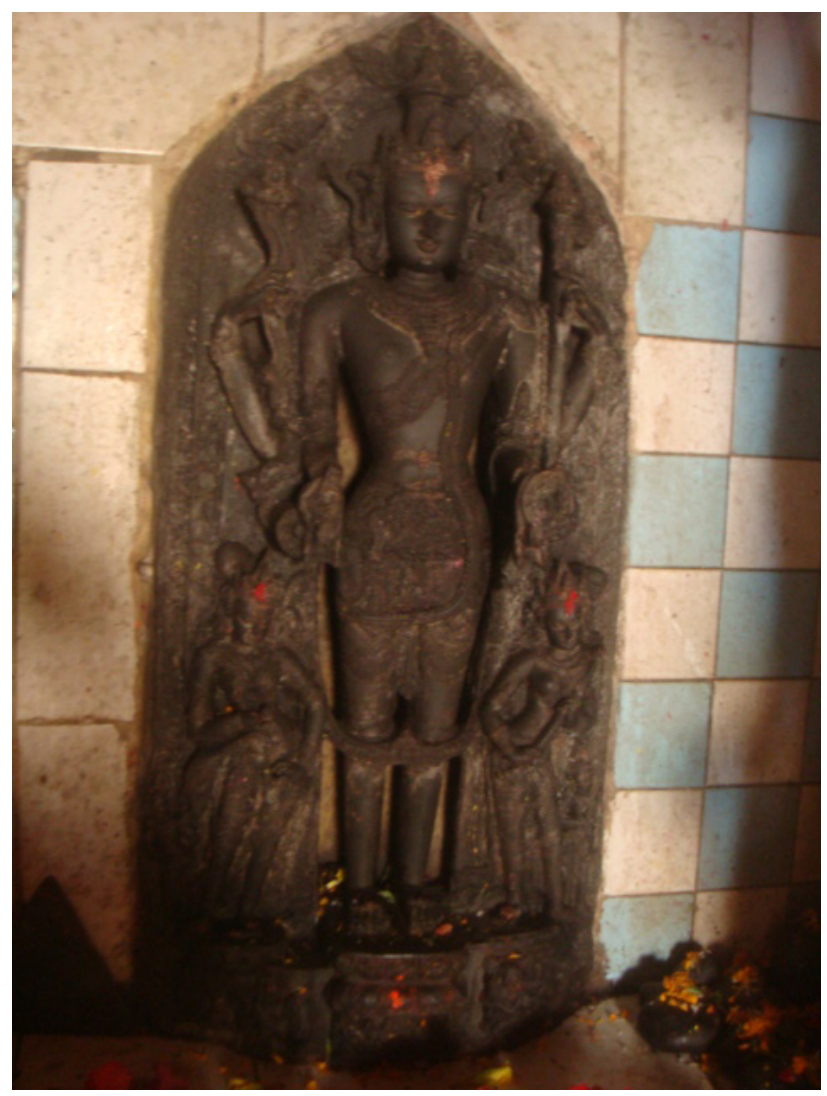

Vishnu of Janakapur

\section{Reference}

Amatya, S. (1978-1979). "Saptariko Chandrabhaga ra Kancha Khoriyaka bhagnvaseșaharu." Ancient Nepal, nos. 49-52 (December 1978 - July 1979), pp. 15-25.

Darnal, Prakash,(2012), Preliminary report on khoksar excavation in 2061/62, Ancient Nepal,no,180,DoA, kathmandu,p.no. 6/40

Darnal, P. (,2016,)Archaelogy of Nepal, ed. Gwen Robbins Schug and Shuhash R. Walimbe, A companion to South Asia in the past, Willey Blackwell,U.K. p.no. 414-416.

Joshi, K. L, (1997). Prithivima Manavko Aagman : Banmanus dekhi Adhunik manav samma yek charcha, Contribution to Nepalese Studies, vol .24, no .1 January 1997, Nepal ra Yesiyali Anusandhan Kendra, T. U . Kirtipur, p.no .81

Khanal, M. P. (2056). Simraongarh ko Itihas, Nepal ra Yeshiyali Anusandhan Kendra,T.U. Kirtipur, Kathmandu, p.no. 15/16.

Pandey,R. (1999). An Introduction to the History and Art Traditions of Mithila, ed. Yogendra p. Yadav, Readings in Maithali Language, Literature and Culture, Royal Nepal Academy, Kath. P.no. 182/ 184 .
Shah, R. B. \& Shrestha R. (1992). Fossils from Nepal Himalaya displayed in Natural Museum,Kathmandu, Journal of Natural History Muesum 13, PP. 1-4.

Sharma, P. R. (2056). Simraongarh ko Itihas, Nepal ra Yeshiyali Anusandhan Kendra,T.U. Kirtipur, Kathmandu, p.no. Foreword.

Shrestha, S. S. (2007). Khaptedanda. Ancient Nepal, no. 164, DoA, Kathmandu, PP 1-3

Tripathee, C. P. (2057). Simraongarh ko puratattwik adhyayan, Ram Dayal Rakesh, Simraongarh vishayak Sanghosthi, Royal Nepal Academy, Kathmandu. p 25. Jewels of Simroungarh, A visual ride to past (2018). TMNC \& Simroungarh municipality.

Darnal, Prakash (Orcid: https://orcid.org/0000-00020927-1574) is archaeologist, former chief of National Museum, Chauni of Nepal. His research focuses on field archaeology, art, monument and culture. He had carried out excavation at Khoksar (Saptari), Dhangadhi, Vidhyapatigadh (Siraha), Manimandap (Dhanusha), Devdaha, Bhawanipur (Rupandehi), Shreekot (Acham) and Surkhet (Katkuwa). He has published hundred of articles in Nepali and English in Journals of Nepalese Studies, Ancient Nepal, The Rising Nepal, The Kathmandu Post, Rolamba, Garima, Madhuparka, Gorkhapatra, Pragya etc. A book, "Hamro Sanskritik Dharoharharu" published in B.S. 2073. He has presented his paper in Annual Conference of H.N.B. Garwal University Srinagar in 1997, SAARC International Conference on Archaeology of Buddhism at Colombo in 2012 and $5^{\text {th }}$ International Congress of Society of South Asian Archaeology, 2014 in Raipur, India. He earned Master of Arts in History from Tribhuvan University, Kirtipur. He was under secretary in Nepal Government's civil service. He got Post Graduate Diploma in Archaeology from Institute of Archaeology (Archaeological Survey of India) New Delhi in 1996-98 AD. He has visited India, China, Srilanka and Germany.

Email: darnalp@gmail.com 